\title{
CONSTRUCTION AND PERFORMANCE EVALUATION OF A SCREW PRESS MACHINE TO EXTRACT JATROPHA OIL
}

\author{
Samar M.M. Habib ${ }^{* 1}$, M.M.A. El-Sharabasy ${ }^{2}$, M.M. Badr ${ }^{1}$ and M.M. El-Kholy ${ }^{3}$ \\ 1. Agric. Eng. Dept., Agric. Fac., Zagazig Univ., Egypt \\ 2. Agric. Eng. Dept., Agric. Fac., Domiat Univ., Egypt \\ 3. Agric. Eng. Res. Inst., Doki., Egypt
}

Received: 25/06/2019; Accepted: 21/07/2019

\begin{abstract}
Utilization of biofuel produced from Jatropha oil represents one of the most promising options for the use of conventional fossil fuels. Biofuel via biodiesel, a promising substitute as an alternative fuel has gained significant attention due to the predicted shortness of conventional fuels and environmental concern. Experiments were carried out through two successful agricultural seasons of 2016 and 2017 at Department of Agricultural Engineering, Faculty of Agriculture Zagazig University to constract and evaluate the performance of a screw press machine suitable for Jatropha seeds. The performance of the screw press was estimated under four different machine capacity and four different seed moisture contents. The performance of the screw press was evaluated taking into consideration oil yield, extraction efficiency, specific energy and operational cost. The experimental results represented that the highest value for each of oil yield and extraction efficiency was $43 \mathrm{~kg} . \mathrm{hr}^{-1}$ and $81 \%$, respectively and also the values of specific energy and operational cost were $258 \mathrm{~kW} \cdot \mathrm{hr}^{-\mathrm{Mg}^{-1}}$ and 1229 LE. $\mathrm{Mg}^{-1}$, respectively at moisture contents of $12 \%$ and machine capacity of $166 \mathrm{~kg} \cdot \mathrm{hr}^{-1}$
\end{abstract}

Key words: Jatropha seed, screw press, extraction, biofuel, jatropha oil, seed moisture content.

\section{INTRODUCTION}

Jatropha curcas L., a perennial plant grown in tropics and subtropics is popularly known for its potential as biofuel. The plant is reported to survive under varying environmental conditions having tolerance to stress and an ability to manage pest and diseases. Jatropha is a droughtresistant shrub or tree, which is widely distributed in wild or semi-cultivated areas in Central and South America, Africa, India, China and South East Asia. In the forthcoming years, 1-2 million hectares of Jatropha curcas L. are expected to be annually planted, reaching 12.8 million hectares worldwide (Contran et al., 2012).

Jatropha can be used as cooking/lighting fuel, bio-pesticide, organic fertilizer, combustible fuel, and for soap making (Karaj and Müller, 2009).

\footnotetext{
*Corresponding author: Tel. : +201153557546

E-mail address: samarhabib454@gmail.com
}

The capability to grow on poor quality soils not suitable for food crop makes jatropha oil a possible solution of all the controversies related to biodiesel production. The energy crisis born from the oil problem determined a renewal of attention on the possible possibilities of production of substitute fuels for the operation of the machines and the thermal engines. The fuel's production based on vegetable oils requires a renewal attention about the research of replacement fuel for the operating of machines and thermal engines. So, for helping to solve the fuel problem by construction of a screw press machine for jatropha oil extraction.

Singh et al. (2008) reported that jatropha seeds have oil percentage $29 \%$ with oil recovery $85 \%$ by using mechanical expeller. Moreover, it has been found that all components of the Jatropha fruits can be utilized efficiently for energy purposes. 
Haque et al. (2009) studied the physical and mechanical properties of jatropha and castor seeds. Physical properties such as length, width, thickness, weight and bulk density were measured to find out the size, shape and space required by the seeds. Mechanical properties like hardness and crushing strength of the seeds were determined as well. Hardness and crushing strength of the seeds were measured by a Manual Hardness Tester. A length was $17.1 \mathrm{~mm}$ for jatropha and castor. Hardness were found 2.7 and $1.9 \mathrm{~kg}_{\mathrm{f}} \mathrm{mm}^{-2}$, while crushing strength were 38.1 and $26.6 \mathrm{~kg} . \mathrm{cm}^{-2}$ for jatropha and castor seeds, respectively.

Antony et al. (2011) compared between the physical properties for Jatropha oil and diesel fuel for obtaining the base line data for analysis. The physical properties such as density, flash point, kinematic viscosity, cloud point and pour point. The values obtained from the Jatropha oil is closely matched with the values of conventional diesel and can be used in the existing diesel engine without any modification.

Dhale and Modak (2011) mentioned that his screw press method is less capital intensive, technically less extensive, compared with the solvent extraction method and less laborintensive than the aqueous method. It is also continuous, unlike the hydraulic and the aqueous methods that are done batch wise. These advantages of the screw press over the other methods make screw pressing popular and inevitable in future oilseed processing. To increase vegetable-oil production therefore, a good understanding of the working principles of the screw press is desirable.

Azmi et al. (2013) stated the physical and mechanical properties of jatropha fruits such as dimensions, sphericity, bulk density, solid density, porosity, coefficient of static friction on steel, rupture force, deformation at rupture point, deformation ratio at rupture point, hardness. The solid density value of $970 \mathrm{~kg} . \mathrm{m}^{-3}$ was obtained which implies that the fruit could float in water for easy cleaning and separation from foreign materials. The coefficient of static friction was 0.44 on stainless steel. The average values obtained for the detachment force and rupture force at vertical orientation were $16.62 \mathrm{~N}$ and $57.17 \mathrm{~N}$, respectively. They also indicated that physical and mechanical properties are essential for design and development of processing machines.

Chavan et al. (2013) indicated that some plants can used to produced biodiesel like jatropha curcus and Pongamia pinnata etc. and more. There is a best source as a raw material oil for biodiesel production as per ASTM 6751.

Evon et al. (2013) evaluated the feasibility of mechanical pressing to extract oil from jatropha seeds using a twin-screw extruder. Also they found oil extraction yield increased with decreasing temperature and screw rotation speed. Highest oil extraction yield of $70.6 \%$ with lowest residual oil content was obtained under operating conditions of $153 \mathrm{rpm}$ screw rotation speed and $5.16 \mathrm{~kg} / \mathrm{hr}$., inlet flow rate of jatropha seeds. The corresponding expressed oil was inexpensive to produce $71 \mathrm{~W} h \mathrm{hr} \cdot \mathrm{kg}^{-1}$ seed processed or $314 \mathrm{~W} \mathrm{hr} . / \mathrm{kg}$ expressed oil for specific mechanical energy compared with another continuous technique commonly used for mechanical extraction of jatropha oil. Its quality was also satisfactory for biodiesel production. The density and the kinematic viscosity of oil were $915 \mathrm{~kg} \cdot \mathrm{m}^{-3}$ and $36.7 \mathrm{St}$.

El-Nono and Abdel-Gawad (2015) tested and evaluated the expelling machine at five screw speeds $25,35,45,55$, and $65 \mathrm{rpm}$ and four levels of press head clearance 0.5, 1, 1.5, and $2 \mathrm{~mm}$ to determine the best machine capacity, percentage of oil recovery, percentage of residual oil and specific energy consumption. The results showed that the maximum machine capacity was $39 \mathrm{~kg} \cdot \mathrm{h}^{-1}$ of raw material at $2 \mathrm{~mm}$ outlet clearances and $65 \mathrm{rpm}$ of screw speed. The best operating pressing conditions for the wheat germ oil recovery was $45.7 \%$ at the 25 rpm of screw speed and $0.5 \mathrm{~mm}$ press head clearance, when the required specific energy was $0.0232 \mathrm{~kW} \cdot \mathrm{hr} \cdot \mathrm{Mg}^{-1}$.

The present study aims to investigate the effect of feeding rate and moisture content on jatropha oil extraction using local screw press machine.

\section{MATERIALS AND METHODS}

Field experiments were carried out through two successful agricultural seasons of 2016 and 2017 at Department of Agricultural Engineering, 
Faculty of Agriculture Zagazig University to construct and evaluate the performance of a screw press machine suitable for jatropha oil extraction.

\section{Manufactured Screw Press Machine}

A screw press machine was designed and manufactured from low cost, local material to overcome the problems of high power and high cost requirements under the use of the imported machines. The screw press machine was manufactured specially for this work and constructed at a private workshop in Sharkia Governorate. The manufactured machine consists mainly of screw shaft, press vessel, choke plate, oil outlet and cake outlet, seed hopper, power source and transmission system is shown in Fig. 1.

\section{Screw shaft}

A screw with tapered root type was designed to provide rate of pressure increase depending on the taper angle of the shaft compared to straight screw shaft. The length of the screw was $650 \mathrm{~mm}$ with outside diameter of $70 \mathrm{~mm}$ to give clearance between screw and barrel.

The root diameter was inclined through the screw with thread depth decreases continuously along the screw shaft as shown in Fig. 2. There is a small clearance between the vessel and the screw shaft by $4 \mathrm{~mm}$. In such a case, friction force between the screw shaft and vessel increases, and required torque becomes higher.

\section{Press vessel}

Vessel is the cage of the screw shaft. Vessel is supposed to canalize the compressed cake, allow oil to flow back and flow out of the vessel in order to prevent any choking. So, important points while designing the vessel mainly depend on two zones which are the oil drainage holes and the grooves inside surface of the vessel.

The vessel material is selected as mild steel piping ANSI/ASME B31.3 for the ease of manufacturing. The maximum tensile stress of this material is $450 \mathrm{MPa}$. With a factor of safety of 1.5 , the maximum available stress inside the vessel can be $300 \mathrm{MPa}$ by thickness of $25 \mathrm{~mm}$. The length, internal diameter and thickness were 480, 90 and $10 \mathrm{~mm}$, respectively. Also $60 \times 60$ $\mathrm{mm}$ opening for mounting of hopper was machined from $60 \mathrm{~mm}$ distance at the beginning of the vessel. Oil drain openings of $150 \mathrm{~mm}$ length were drilled at the bottom mid zone of the vessel with breadth of $40 \mathrm{~mm}$. A flange was welded to the end of the barrel to support the die plate.

\section{Seed hopper}

A square frustum-shaped hopper was constructed and mounted at the intake of the press vessel. It was constructed from $2 \mathrm{~mm}$ thick MS sheet. The height, top (inlet) opening and bottom (exit) opening to press barrel. The height of the frustum is $250 \mathrm{~mm}$ and it has a square top of length $200 \mathrm{~mm}$. Provision for feed-rate control device and two slide rails (on which the feed rate control device moves) are provided. By this means, the quantity of seeds entering into the vessel per unit time can be regulated.

\section{Oil drainage zone}

The oil channel was U-shaped, inclined at angle of $15^{\circ}$ to the horizontal. Oil flows from the high-pressure zone to the low-pressure zone until it finds an opening to rush out. For oil drainage, holes are machined onto the vessel. Oil drain openings had an extent of $2.5 \mathrm{~mm}$ with a length of $150 \mathrm{~mm}$. These openings should be far enough from the cake drainage zone at where the pressure is maximum, otherwise the holes can be choked with high pressurized cake. Therefore, oil drainage holes should be placed where the seeds are not compressed yet.

\section{Cake outlet}

The cake outlet was located at the end of the press vessel. A circular channel with open ends was used for cake outlet and it was made from mild steel of $25 \mathrm{~mm}$ thickness and length of 50 $\mathrm{mm}$. The cake outlet channel extended from the choke plate.

\section{Power Source and Transmission System}

The press screw machine was powered by an electric motor $11.03 \mathrm{~kW}(15.00 \mathrm{hp})$ at a rated speed of $90 \mathrm{rpm}$. Two pulleys diameter $150 \mathrm{~mm}$ and $300 \mathrm{~mm}$ were fixed on screw shaft and the prime mover and was connected through V-belt. The power is transmitted from the power source to the other moving parts by means of pulleys and V-belt with different speed ratios because it can easily be installed and removed. 

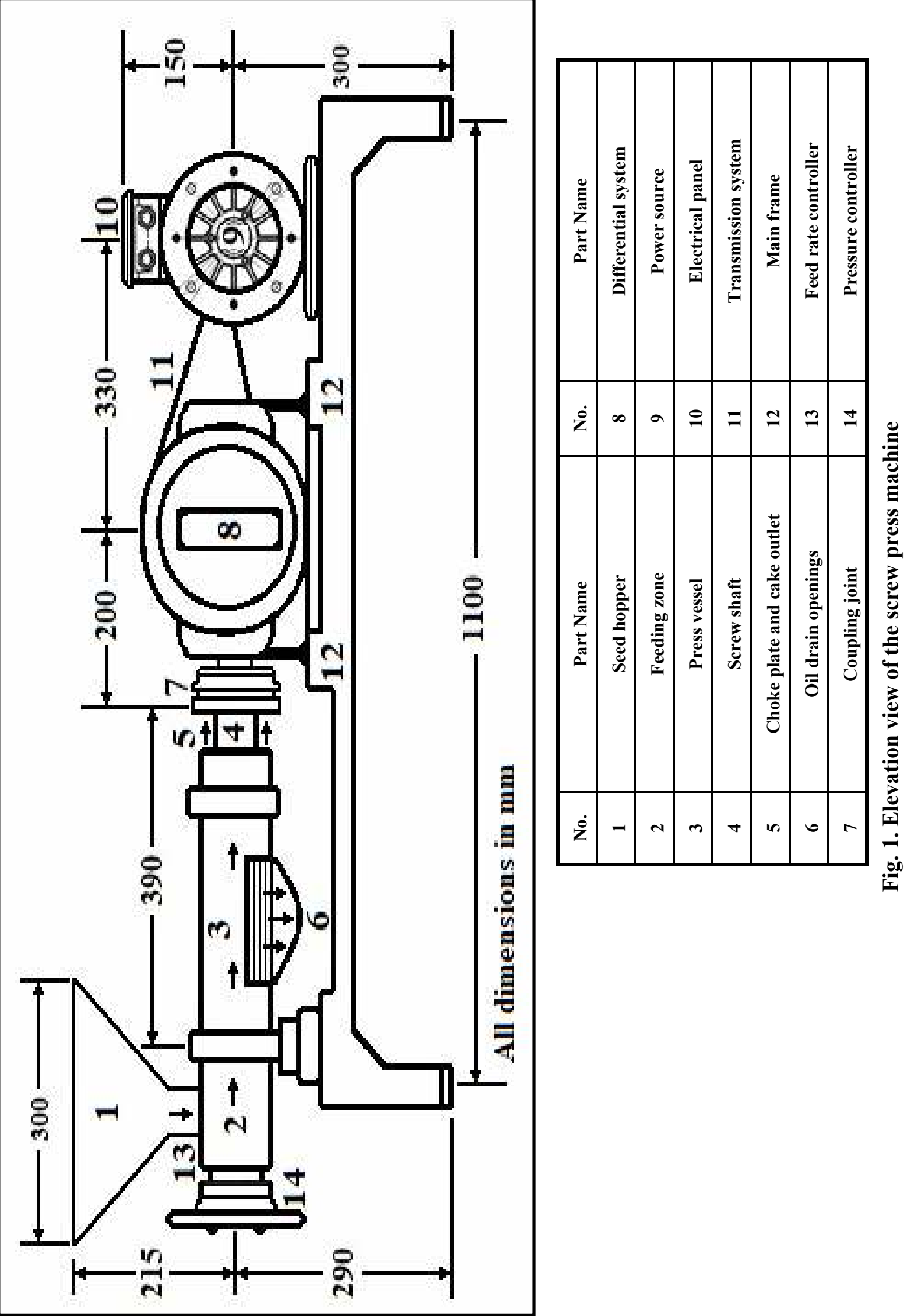

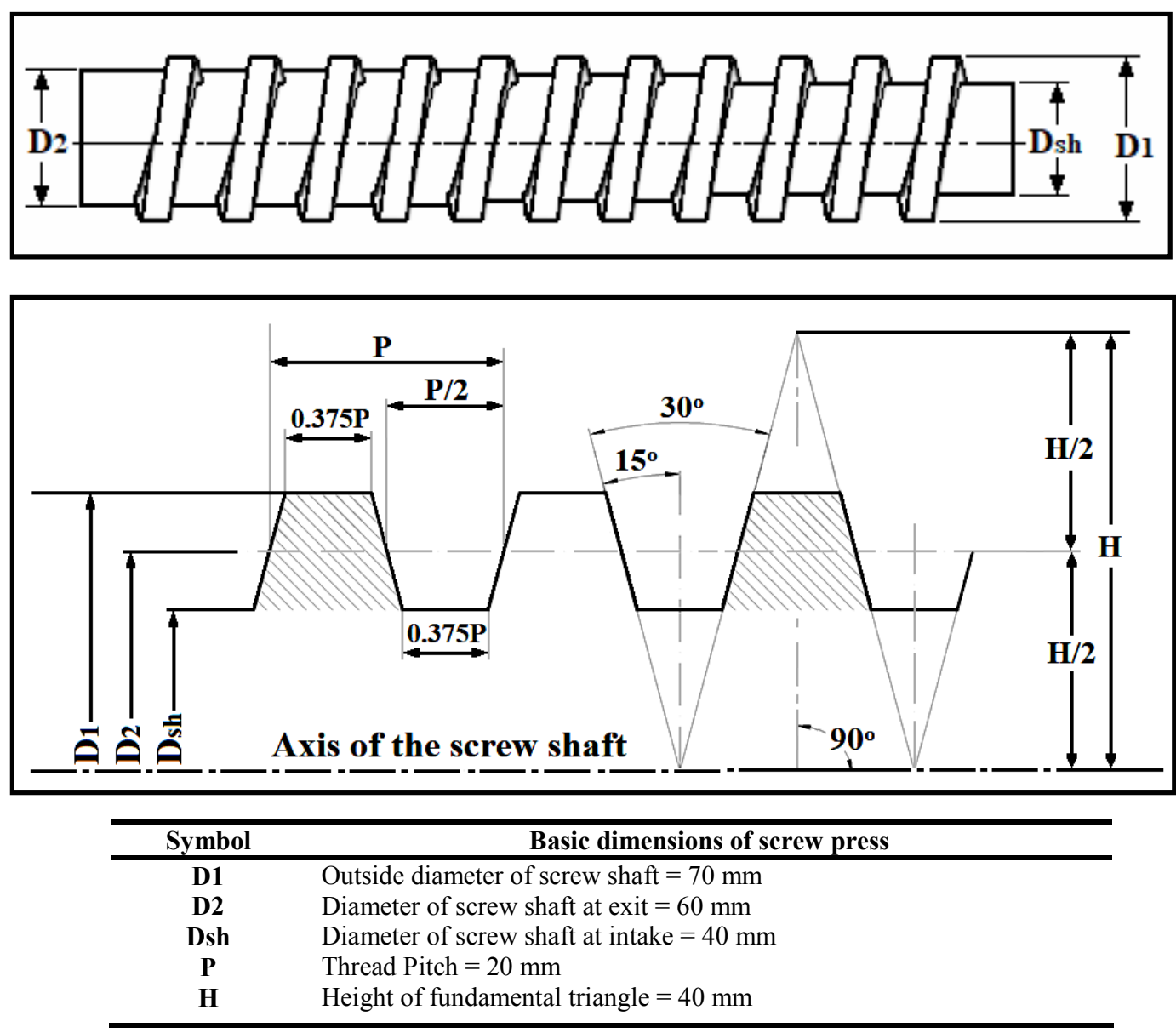

Fig. 2. Screw press with trapezoidal thread type and basic dimensions of screw press shaft

\section{Design of Screw Press Machine}

\section{The screw threads}

The worm shaft is primarily a sharpened screw conveyor with the volumetric displacement being decreased from the feed limit of the press barrel to the discharge limit. The screw treading system was design as a step shaft and decreasing screw depth using the following equation (Khurmi and Gupta, 2005).

Where:

$$
\mathrm{d}_{\mathrm{d}}=\mathrm{d}_{\mathrm{f}}-(\mathrm{n}-1)
$$

$d_{d}=$ screw depth at the discharge end.

$\mathrm{d}_{\mathrm{f}}=$ screw depth at the feed side $=15 \mathrm{~mm}$.

$\mathrm{n}=$ number of screw turns $=11$.

Accordingly, the screw depth would be decreased consistently from 15 to $5 \mathrm{~mm}$ of the feed end up to the discharge end of the screw press.

\section{Screw shaft}

The screw shaft is the major component of the screw press machine and is acted upon by materials treatment and screw thread. During the extraction process, the shaft squeezes and conveys the seeds for jatropha oil extraction under level of high pressure. Therefore, a mild steel bar grade-A694 F60 was used for designing the screw shaft with yield strength, ultimate tensile strength and elongation percentage as $414 \mathrm{~N} \cdot \mathrm{mm}^{-2}, 517 \mathrm{~N} . \mathrm{mm}^{-2}$ and $20 \%$, respectively. To safeguard against tensional stresses and bending, the diameter of the worm shaft was determined from the following equation (Khurmi and Gupta, 2005; Ojolo et al., 2012).

$$
\mathrm{D}_{\mathrm{sh}}=\frac{16 \mathrm{Ft}}{0.27 \pi . \delta \mathrm{o}}(2)
$$


Where:

$\mathrm{D}_{\mathrm{sh}}=$ diameter of the screw shaft $=37.38 \mathrm{~mm}$.

The force transmitted by the shaft per length unit, $\mathrm{Ft}=820 \mathrm{~N} \cdot \mathrm{mm}^{-1}$ and $\delta \mathrm{o}=$ the yield stress for mild steel $=414 \mathrm{~N} \cdot \mathrm{mm}^{-2}$. The standard of A694 is more rigorous than the more common grades, providing more robust specifications for high-pressure fluid transmission in oil and gas piping systems. The total length of the shaft is $650 \mathrm{~mm}$ with a diameter $40 \mathrm{~mm}$ based on physical requirement. The screw winding covered a length of $480 \mathrm{~mm}$, leaving a distance of $150 \mathrm{~mm}$ and $270 \mathrm{~mm}$ for seed intake and pressed cake outlet side, respectively. These dimensions facilitate mounting of bearings and pulleys.

\section{The produced pressure}

The pressing area and the pressure produced by the screw thread were determined by the following equations:

$$
\mathrm{A}_{\mathrm{P}}=\pi \mathrm{D}_{\mathrm{m}} \text { nh and } \mathrm{P}_{\mathrm{r}}=\frac{\mathrm{W}_{\mathrm{e}}}{\mathrm{A}_{\mathrm{P}}} \text { (3) }
$$

Where:

$\mathrm{P}_{\mathrm{r}}$ and $\mathrm{A}_{\mathrm{p}}=$ pressure produced and pressing area by the screw thread.

$\mathrm{h}=$ screw depth maximum pressure at discharge end.

By compensate for a value, $D_{m}=40 \mathrm{~mm}$, $\mathrm{n}=10, \mathrm{hr} .=5 \mathrm{~mm}$ and $\mathrm{W}_{\mathrm{e}}=10.482 \mathrm{kN}$.

Hence, $A_{p}=6280 \mathrm{~mm}^{2}$ and $P_{r}=1.67 \mathrm{MPa}$. In other words, a pressure of $1.67 \mathrm{MPa}$ would be available for squeezing jatropha oil from the cake during operation.

The pressure that can be also withstood by the vessel was determined by the equation presented by (Khurmi and Gupta, 2005) as:

$$
\mathrm{P}_{\mathrm{V}}=\frac{2 \mathrm{t} \delta \mathrm{a}}{\mathrm{D}_{\mathrm{i}}}
$$

Where:

$\mathrm{P}_{\mathrm{V}}=$ pressure to be withstood by the vessel.

$t$ and $D_{i}=$ thickness and the internal diameter of the vessel. $\delta \mathrm{a}=$ allowed stress $(0.27 \delta o)$ and $\delta o=$ the yield stress of mild steel.

Hence, $\delta \mathrm{a}=111.78 \mathrm{MPa}$ and $\mathrm{P}_{\mathrm{b}}=24.84$ MPa. Which means that the pressure that the vessel can withstand equal to $24.84 \mathrm{MPa}$ is greater than the pressure produced by the worm screw which reaches $1.67 \mathrm{MPa}$ for jatropha oil extraction. Therefore, the vessel will be withstanding the extraction pressure without an explosion.

\section{The power required of the electric motor}

The power required of the electric motor to drive the press screw was determined using the equation below as:

$$
\mathrm{P}_{\mathrm{m}}=\frac{\mathrm{P}_{\mathrm{S}}}{\eta_{\mathrm{m}} \times \eta_{\mathrm{t}}}
$$

The power required to drive the press screw was estimated by using the following equation:

Where:

$\mathrm{P}_{\mathrm{m}}=$ power of the electric motor.

$\mathrm{P}_{\mathrm{S}}=$ power required to drive the screw press.

$\eta_{\mathrm{m}}=$ mechanical efficiency.

$\eta_{\mathrm{t}}=$ transmission efficiency.

$$
\mathrm{P}_{\mathrm{S}}=4.5 \mathrm{Q}_{\mathrm{V}} \cdot \mathrm{L}_{\mathrm{S}} \cdot \rho \cdot \mathrm{g}
$$

Where:

$\mathrm{Q}_{\mathrm{V}}=$ volumetric capacity of the worm shaft and Ls is length of worm shaft. Substituting by $\mathrm{Q}_{\mathrm{V}}=0.419 \mathrm{~m}^{3} \cdot \mathrm{hr}^{-1}$ and $\mathrm{L}_{\mathrm{S}}=650 \mathrm{~mm}$.

Accordingly, $\mathrm{P}_{\mathrm{S}}=5.71 \mathrm{~kW}, \mathrm{Pm}=9.52 \mathrm{~kW}$ (12.94 hp). Therefore, the electric motor for the oil extraction machine selected based on the load specifications of the machine is a threephase $50 \mathrm{~Hz}$ motor for industrial purpose. An electric motor with a power rating of (15hp) was selected to drive the press screw. For selecting the motor, it was assumed that the electric motor operates continuously at full load.

\section{Experimental Parameters}

The performance of the evaluated machine was experimentally measured under the following parameters: 
- Four different seed moisture contents $(8,12$, 17 , and $22 \%$ ) of jatropha seeds.

- Four different machine capacities $(101,125$, 148 , and $166 \mathrm{~kg} / \mathrm{hr}$.).

\section{Measurements and Determinations}

Evaluation of the performance of extracting machine was based on the following indicators:

\section{Machine capacity}

Machine capacity was determined by the following equation:

$$
\mathrm{Mc}=\frac{\mathrm{Ms}}{\mathrm{t}}(7)
$$

Where:

$\mathrm{Mc}=$ machine capacity, kg.hr. ${ }^{-1}$.

$\mathrm{Ms}=$ Weight of input sample, $\mathrm{kg}$

$\mathrm{t}=$ time required to empty the hopper, $\mathrm{hr}$.

\section{Oil yield}

Oil yield of screw shaft can be estimated using the following equation:

$$
\mathrm{Oy}=\frac{\mathrm{Wo}}{\mathrm{tc}}
$$

Where:

Oy $=$ crude oil yield, $\mathrm{kg} . \mathrm{hr}^{-1}$.

Wo $=$ weight of crude oil extracted, $\mathrm{kg}$.

$\mathrm{tc}=$ time consumed to extract the seed sample, $\mathrm{hr}$.

\section{Extraction efficiency}

Extraction efficiency was determined using the following equation:

$$
\eta_{\mathrm{e}}=\frac{\text { Woc }}{\text { Oc }}
$$

Where:

$\eta_{\mathrm{e}}=$ Extraction efficiency, (\%).

$\mathrm{W}_{\mathrm{oc}}=$ Weight of oil collected, $\mathrm{kg}$.

$\mathrm{O}_{\mathrm{c}}=$ Weight of oil content in test sample, $\mathrm{kg}$.

\section{Flow rate of the cake}

The mass flow rate of the cake can be determined by using the following equation:
$\mathrm{Q}_{\mathrm{c}}=\frac{\mathrm{Qs}}{\mathrm{tc}}$

Where:

$\mathrm{Qc}=$ flow rate of the cake, $\mathrm{kg} \cdot \mathrm{hr} .^{-1}$.

$\mathrm{Qs}=$ weight of cake from compressed seed, $\mathrm{kg}$.

\section{Energy requirements}

The energy requirements for the extraction process can be calculated as follows:

$$
\mathrm{E}=\frac{\mathrm{Pm}}{\mathrm{Oy}}
$$

Where:

$\mathrm{E}=$ specific energy, $\mathrm{kW} \cdot \mathrm{hr} \cdot \mathrm{Mg}^{-1}$

\section{Operational cost}

The operational cost required for the extraction process was estimated using the following equation:

$$
\mathrm{Oc}=\frac{\mathrm{Mc}}{\mathrm{Oy}}
$$

Where:

Oc $=$ Operational cost, LE. $\mathrm{Mg}^{-1}$.

$\mathrm{Mc}=$ Machine cost, LE.hr. ${ }^{-1}$.

Oy $=$ Oil yield, Mg.hr. ${ }^{-1}$.

The machine cost was determined considering conventional method of estimating both fixed and variable costs (Kepner et al., 1982; Hunt, 1983) according to price level of 2018.

\section{RESULTS AND DISCUSSION}

The obtained results will be discussed under the following items:

\section{Influence of Machine Capacity on the Oil Content and Oil Extraction Efficiency at Different Moisture Contents}

The results showed that the oil content and oil extraction efficiency inversely with machine capacity is shown in Fig. 3. It is clear that the oil content and oil extraction efficiency was increased by increasing machine capacity up to $148 \mathrm{~kg} . \mathrm{hr} .^{-1}$, any further increase in machine capacity up to $166 \mathrm{~kg} . \mathrm{hr}^{-1}$ for the same seed decreased oil content and oil extraction efficiency. Obtained results showed that increasing 

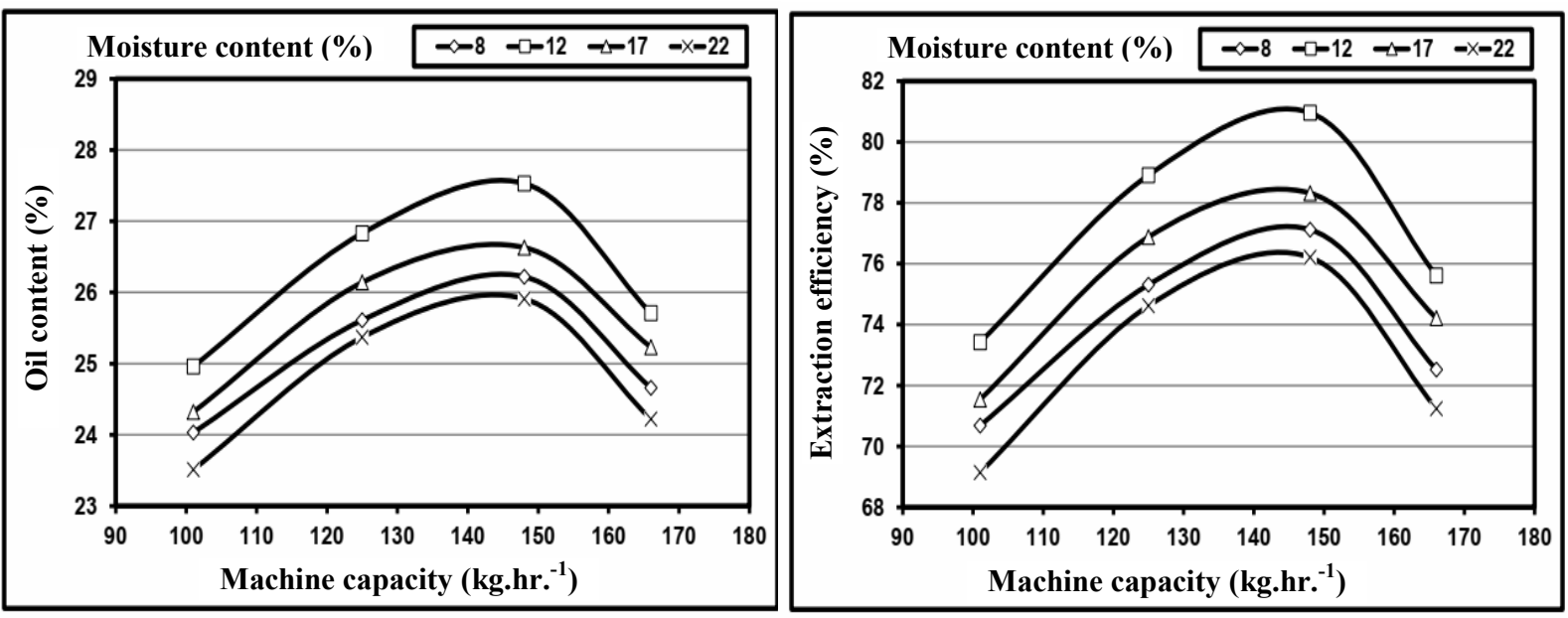

Fig. 3. Effect of machine capacity on oil content and extraction efficiency

machine capacity from 101 to $148 \mathrm{~kg} \cdot \mathrm{hr}^{-1}$ measured at different moisture content of about $8,12,17$ and $22 \%$ increased the oil content from 24.03 to 26.22 , from 24.96 to 27.53 , from 24.32 to 25.23 and from 23.51 to $25.91 \%$, also increased oil extraction efficiency from 70.68 to 77.12 , from 73.42 to 80.96 , from 71.54 to 78.32 and from 69.14 to $76.21 \%$, respectively. Any further increase in machine capacity more than 148 up to $166 \mathrm{~kg} \cdot \mathrm{h}^{-1}$ measured at the same previous moisture content decreased the oil content from 26.22 to 24.66 , from 27.53 to 25.71, from 26.63 to 25.23 and from 25.91 to $24.22 \%$, also decreased oil extraction efficiency from 77.12 to 72.52 , from 80.96 to 75.61 , from 78.32 to 74.21 , and from 76.21 to $71.24 \%$, respectively.

\section{Influence of Machine Capacity on the Oil Yield and Cake Recovery at Different Moisture Content}

The results cleared that oil yield and cake recovery was increased by increasing machine capacity from 101 to $166 \mathrm{~kg} . \mathrm{hr}^{-1}$ for jatropha seed as shown in Fig. 4. The results showed that increasing machine capacity from 101 to 166 $\mathrm{kg} . \mathrm{hr} .^{-1}$ measured at different moisture content of about $8,12,17$ and $22 \%$ increased oil yield from 24.27 to 40.93 , from 25.21 to 42.68 , from 24.57 to 41.88 and from 23.74 to $40.20 \mathrm{~kg} . \mathrm{hr}^{-1}$, also increased cake recovery from 76.73 to 125.07 , from 75.79 to 123.32 , from 76.43 to 124.12 and from 77.26 to $125.80 \mathrm{~kg} . \mathrm{hr}^{-1}$, respectively.
Influence of Machine Capacity on the Specific Energy and Operational Cost at Different Moisture Content

The results showed that specific energy inversely with machine capacity. It is clear that specific energy was decreased by increasing machine capacity. Obtained results showed that increasing machine capacity from 101 to 166 kg.hr. ${ }^{-1}$ measured at different moisture content of about $8,12,17$ and $22 \%$ decreased specific energy from 454.47 to 269.48 , from 437.52 to 258.43, from 448.92 to 263.37 and from 464.62 to $274.38 \mathrm{~kW} \cdot \mathrm{hr}^{\mathrm{Mg}} \mathrm{Mg}^{-1}$, respectively as shown in Fig. 5. The results showed that operational cost inversely affected with machine capacity. Regarding operational cost it was decreased by increasing machine capacity. The results showed that increasing machine capacity from 101 to 166 $\mathrm{kg} . \mathrm{hr}^{-1}$ measured at different moisture content of about $8,12,17$ and $22 \%$ decreased operational cost from 2162 to 1282 , from 2081 to 1229 , from 2135 to1253 and from 2210 to 1305 LE. $\mathrm{Mg}^{-1}$.

\section{Conclusion}

The performance of the screw press was evaluated taking into consideration oil yield, extraction efficiency, specific energy and operational cost. The experimental results represented that the highest value for each of oil yield and extraction efficiency was $41 \mathrm{~kg} . \mathrm{hr}^{-1}$ and $81 \%$, respectively and also the value of specific energy and operational cost were 258 kW.h. $\mathrm{Mg}^{-1}$ and 1229 LE. $\mathrm{Mg}^{-1}$, respectively at moisture contents of $12 \%$ and machine capacity of $145 \mathrm{~kg} \cdot \mathrm{hr}^{-1}$. 

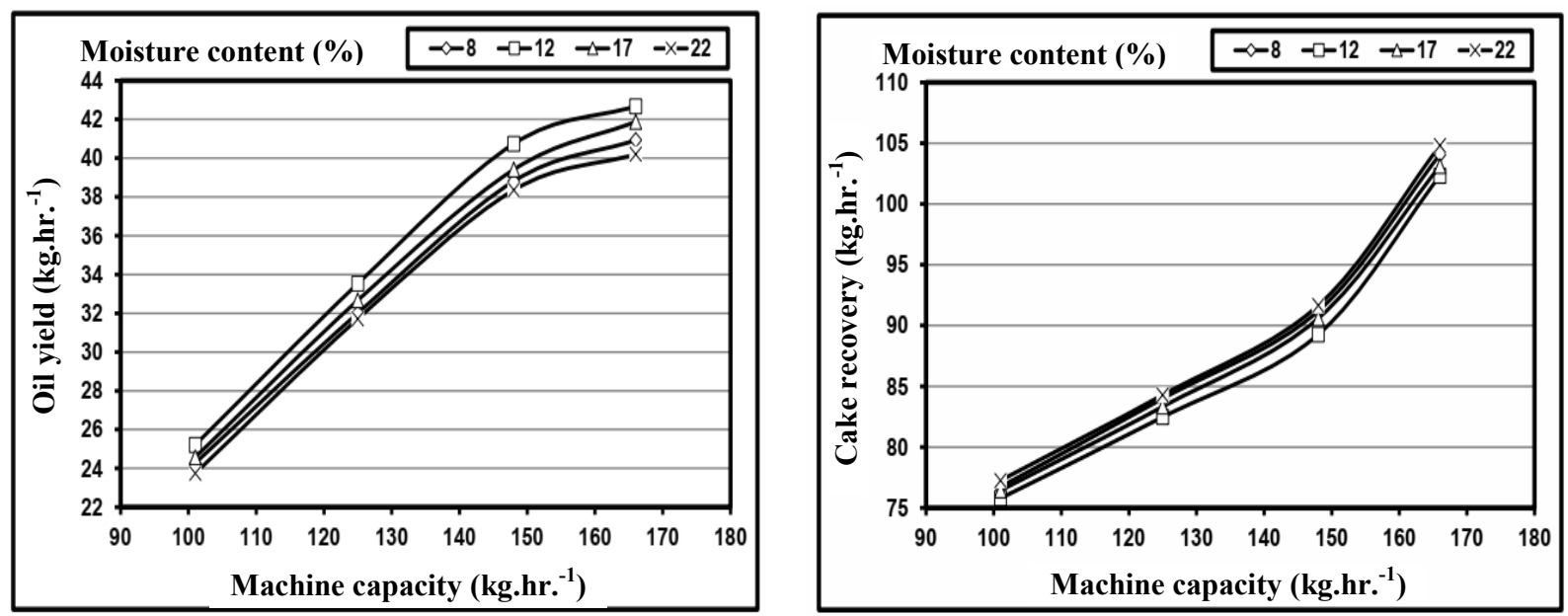

Fig. 4. Effect of machine capacity on the oil yield and cake recovery
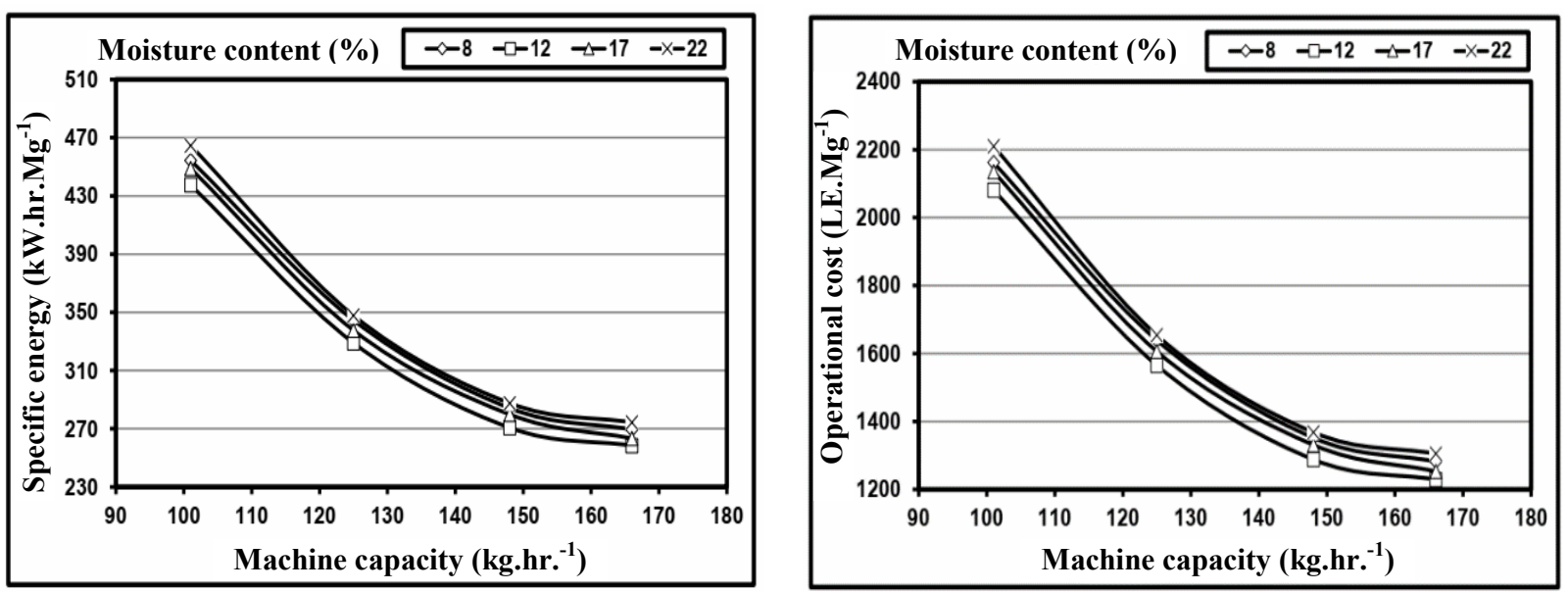

Fig. 5. Effect of machine capacity on specific energy and operational cost

\section{REFERENCES}

Antony, R.S., D.S. Robinsonsmart and C.L.R. Lee (2011). Biodiesel production from Jatropha oil and its characterization. Res. J. Chem. Sci., $1: 81-87$.

Azmi, Y., H. Khairunnise, T. AbiodunIshola and H. Suryanto (2013). Physical and mechanical properties of Jatropha curcas L. fruits from different planting densities. J. Appl. Sci., 13 (7): 1004-1012.

Chavan, S.B., R.R. Kumbhar and R.B. Deshmukh (2013). Callophyllum inophyllum linn ("honne") Oil, A Source for Biodiesel Prod. Res. J. Chem. Sci., 3 (11): 24-31.
Contran, N., L. Chessa, M. Lubino, D. Bellavite, P.P. Roggero and G. Enne (2012). State-ofthe art of Jatropha curcas productive chain: from sowing to biodiesel and by products. Industrial Crops and Prod., 42 : 202- 215.

Dhale, A.D. and J.P. Modak (2011). Design and development of oil seed presser by using energy source as human powered flywheel motor. Int. J. Agric. and Food Sci. Technol., 2 (1): 63-72.

El-Nono, A. and A.M. Abdel-Gwad (2015). Basic design criteria of expelling machine for extracting wheat germ oil.

Evon, P.H., A. Kartika, M. Cerny and L. Rigal (2013). Extraction of oil from jatropha seeds 
using a twin-screw extruder: Feasibility study. Industrial Crops and Prod., 47: 33- 42.

Haque, M.A., M.P. Islam, M.D. Hussain and F. Khan (2009). Physical, mechanical properties and oil content of selected indigenous seeds available for biodiesel production in bangladesh. Agric. Eng. Int., 1419: 840-845.

Hunt, D. (1983). Farm Power and Machinery Management. $8^{\text {th }}$ Ed. Iowa state Univ., Press Ames, USA. Ames, Iowa, USA: 364-368.

Karaj, S. and J. Müller (2009). Optimization of mechanical extrac-tion of Jatropha curcas seeds. Landtechnik, 3:164-167.Očenášek J., Voldřich J., Mathemat.

Kepner, R.A., B.R. Bainer and E.L. Barger (1982). Principles of Farm Machinery. $3^{\text {rd }}$
Ed., Pub. by the AVI Pub. Co. 23-47 and 209236.

Khurmi, R.S. and J.K. Gupta (2005).A textbook of Machine Design. Eurasia Publishing House (Pvt) LTD. RAM Nagar, New Delhi. 110055.

Ojolo, S.J., J.I. Orisaleye and S.O. Ismail (2012). Design of a jathropha oil expelling machine. J. Emerging Trends in Eng. and Appl. Sci. (JETEAS), 3 (3): 412-419.

Singh, R.N., D.K. Vyas, N.S.L. Srivastava and N. Madhuri (2008). Sprier experience on holistic approach to utilize all parts of Jatropha curcas fruit for energy. Renewable Energy, 33: 1868-1873.

$$
\begin{aligned}
& \text { تصنيع وتقييم أداء آلة الضغط البريمية لاستخراج زيت الجاتروفا }
\end{aligned}
$$

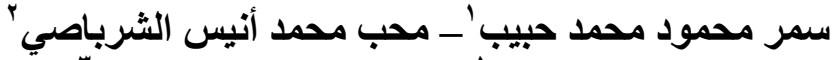

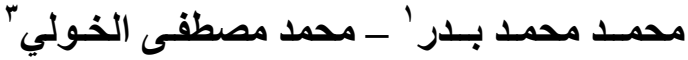

$$
\begin{aligned}
& \text { 1 ـ قسم الهندسة الزر اعية ـ كلية الزر اعة ـ جامعة الزقازيق - مصر }
\end{aligned}
$$

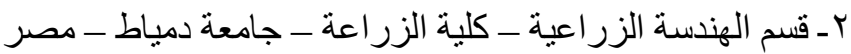

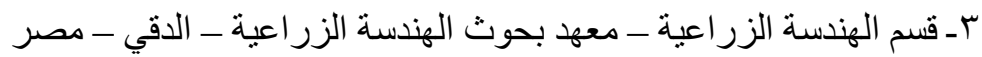

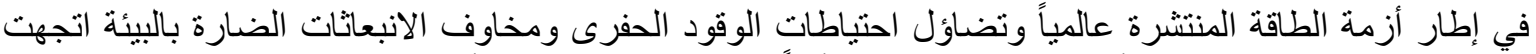

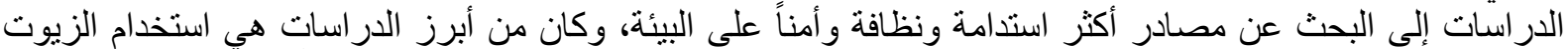

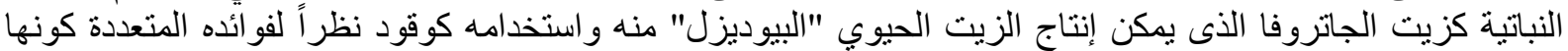

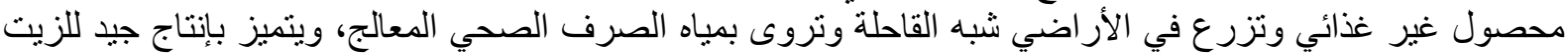

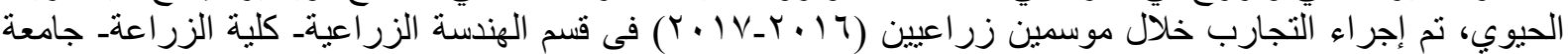

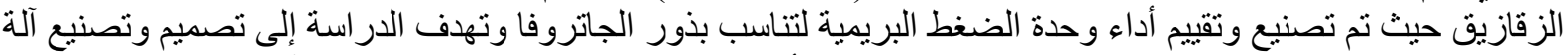

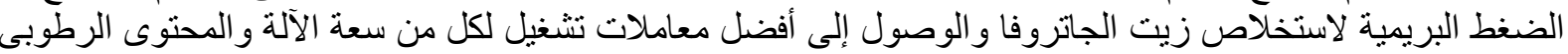

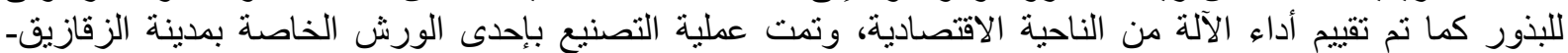

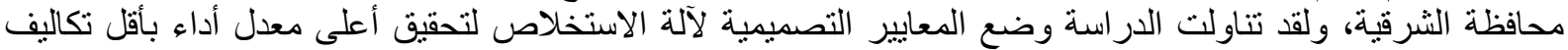

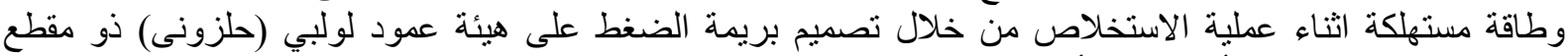

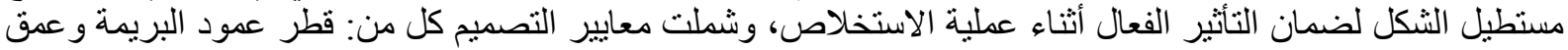

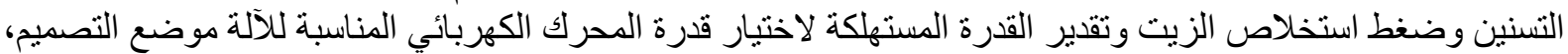

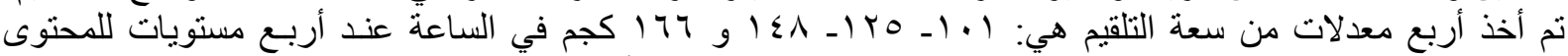

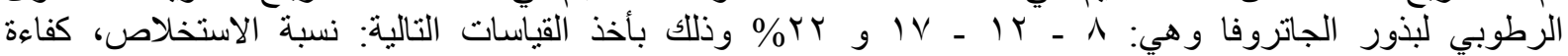

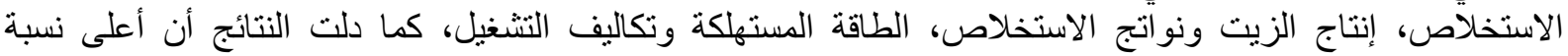

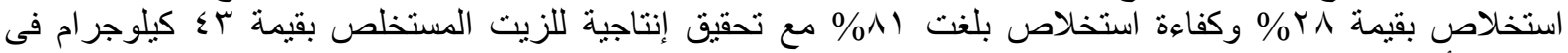

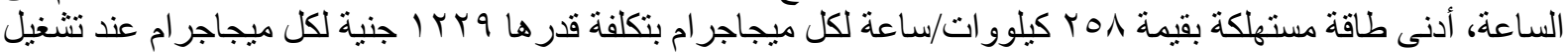

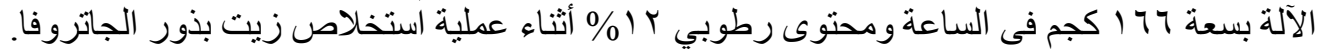

أستاذ الهندسة الزر اعية ـ كلية الزر اعة بالإسماعيلية - جامعة قناة السويس.

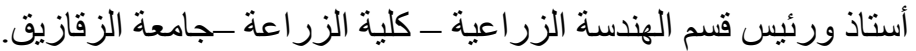

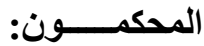

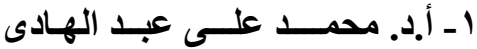

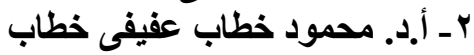

